\title{
Mitteformaalõppe tähenduse konstrueerimine poliitikadokumentides
}

\author{
Katrin Karu ${ }^{\text {al }}$, Larissa Jõgi ${ }^{\text {a }}$, Ilona-Evelyn Rannala ${ }^{a}$, \\ Triin Roosalu ${ }^{\mathrm{b}}$, Lianne Teder ${ }^{\mathrm{a}}$, Halliki Põlda ${ }^{\mathrm{a}}$ \\ a Tallinna Ülikooli haridusteaduste instituut \\ ${ }^{b}$ Tallinna Ülikooli ühiskonnateaduste instituut
}

\begin{abstract}
Annotatsioon
Artikkel tugineb uuringule, mille fookuses on mitteformaalõppe tähendus ja diskursuse muutus Eesti arengut suunavates poliitikadokumentides. Selline rõhuasetus on tingitud asjaolust, et mitteformaalõppe tähendus on sotsiaalselt konstrueeritud, paradigma- ja kontekstispetsiifiline ning sõltub ideoloogiast, hariduspoliitilisest korraldusest, traditsioonidest ja väljakujunenud tavadest. Uurimuses kombineeritakse kriitilist diskursuseanalüüsi poliitikaradade meetodiga ning esitatakse mitteformaalõppe diskursuse ajalise ja valdkondliku kasutuse analüüs. Analüüsi tulemusena eristus kuus valdkondlikku poliitikadokumentide rada, kümme mitteformaalõppe aladiskursust ja viis diskursust: keskkonna-, eristumis-, kaasamis-, süsteemi- ja tunnustamisdiskursus. Mitteformaalõppe tunnustamise diskursus eristus diskursusteülesena ning selles ilmnevad võimalikud edasised muutused mitteformaalõppe sisu ja vormi sotsiaalsel konstrueerimisel poliitikadokumentides.
\end{abstract}

Võtmesõnad: mitteformaalõpe, vabaõpe, mitteformaalne haridus, kriitiline diskursuseanalüüs, poliitikaradade meetod

\section{Sissejuhatus}

Artikli autorid kui täiskasvanuhariduse, noorsootöö ja sotsioloogia valdkonna uurijad ja õppejõud on seisukohal, et mitteformaalõppe (MFÕ) võimalused ja tähendused vajaksid senisest suuremat tähelepanu. Nagu sotsiaalsed tähendused üldisemalt, on ka MFÕ tähendus paradigma- ja kontekstispetsiifiline (Raud, 2013), sõltudes haridussüsteemi institutsionaalsest ja hariduspoliitilisest

Haridusteaduste instituut, Tallinna Ülikool, Narva mnt 25, 10120 Tallinn;

katrin.karu@tlu.ee 
korraldusest, traditsioonidest ning tavadest (Field, 2006; Romi \& Schmida, 2009). Hariduspoliitikas, teadustekstides ja valdkondlikus praktikas on mitteformaalópe ja selle omasõnaline vaste vabaõpe (HKS, 2014) integreeritud elukestva õppe ja õppimise tähendusega ning kasutusel nii teadus-, haridus- ja noortepoliitika tekstides kui ka noorte ning täiskasvanute õppimis- ja õpetamistavades. Samas puudub neis tekstides-tavades mõiste mitteformaalõpe kujunemise ja kasutamise analüüs, mis oleks vajalik hariduspoliitika, riikliku haridussüsteemi ja mitteformaalõpet rakendavate valdkondade - täiskasvanuhariduse ja noorsootöö - korralduse seisukohast ning laiemas, elukestva õppe ja õppimise kontekstis. MFÕ tähenduse mõistmine kujuneb eriti oluliseks siis, kui on vaja arendada ja rakendada mitteformaalõppes osalejatele mõeldud õppekavu ja programme ning valida täiskasvanute ja noorte õppimist ja juhendamist toetavaid käsitusi.

Uurimuse fookuses on MFÕ tähenduste mõistmine. Olukorras, kus süsteemsed uuringud ja usaldusväärsed empiirilised andmed Eesti MFÕ arengu kohta puuduvad, on vaja selgitada mõistestiku kasutamist, konteksti ja diskursuste muutumist ajas. Kontseptuaalsest ja teoreetilisest aspektist on see problemaatika oluline nii ülikoolidele, kes valmistavad ette haridusvaldkonna asjatundjaid, kui ka hariduse, sh täiskasvanuhariduse, andragoogika ja noorsootöö valdkonna spetsialistidele ja praktikutele ning elukestvas ja mitteformaalõppes osalevatele õppijatele. Uuringu kesksed küsimused on: 1) mis MFÕ diskursused on Eesti poliitikadokumentides aja jooksul esile kerkinud; 2) kuidas need diskursused on ajas muutunud ning 3) mis aladiskursuste kaudu konstrueerivad poliitikakujundajad MFÕ tähendust? Empiiriliste andmete analüüsile toetudes näitame, kuidas ja mis kontekstis esinevad mõisted mitteformaalõpe ja selle sünonüüm vabaõpe ning mitteformaalne haridus Eesti strateegilistes arengukavades ja poliitikadokumentides.

\section{Probleemipüstitus ja taust}

Hariduse ja õppimise kontekstis ei ole mõiste mitteformaalõpe selgelt määratletud - see ilmnes esmalt poliitilises ja hariduspoliitilises diskursuses (Coombs \& Ahmed, 1974) ning 1970. aastate algusest ka teaduskirjanduses (Bock \& Bock, 1989; Jarvis, 1987; Tought, 1971). Mõistestiku ja terminoloogia ebamäärasusele Euroopa Liidu poliitikadokumentides on viidanud mitmed uurijad (vt Milana \& Holford, 2014), osutades, et mõisteid elukestev õpe, informaalne ja mitteformaalne haridus kasutatakse hariduspoliitilistes dokumentides süsteemitult ja ebajärjekindlalt ${ }^{2}$. Näiteks hõlmab elukestev õpe kord haridust ja koolitust n-ö

2 Kuna in- on sama mis mitte-, on keeletasandil informaalne ja mitteformaalne sünonüümid. Ka see võib olla üks süsteemitu kasutuse põhjusi. 
hällist hauani, kord on see fookustatud ainult täiskasvanuharidusele (ibid.). Ka pikaajaliste uuringute tulemuse põhjal on järeldatud, et eri strateegiate sidumine Euroopa Liidu dokumentides kasutatud abstraktsete konstruktsioonidega ja/või ideoloogiliste vooludega ei too selgust hariduspoliitilistesse arengusuundadesse ega mõistete kasutusse. Nii ei ole aru saada, „mis põhimõtetel ja milliste tähendustega teatud termineid ja võtmesõnu dokumentides kinnistatakse ja legitimeeritakse“ (Naumanen \& Rinne, 2008, lk 275).

Terminid mitteformaalõpe (ingl non-formal learning) ja mitteformaalne haridus (ingl non-formal education) on teadustekstides rööpkasutusel (Colley, Hodkinson, \& Malcolm, 2003; Duke, 2001; Jarvis, 1990; Livingstone, 2001). Vormiliselt on mõiste määratletud eituse kaudu ning see viitab tegelikkuses eksisteerivatele objektiivsetele vastuoludele, mis on selles kontekstis eriti tähenduslik (vt eituse mõtestamisest keeleteaduses Sang, 1983). Selliste vastuolude tõttu on mõistet esitatud ja kirjeldatud kas formaalsele haridusele vastandudes või selle lisaväärtust ja alternatiivseid võimalusi rõhutades (Colley et al., 2003; Norqvist \& Leffler, 2017). Mitteformaalóppe mitmetähenduslikkus ja kasutamise variatiivsus on viinud selleni, et kontseptuaalne arusaam mitteformaalse õppe ja hariduse tähendusest puudub (Colley et al., 2003; Livingstone, 2001; Naumanen \& Rinne, 2008). Kõige üldisemalt on MFÕd määratletud formaalsest haridusest väljaspool toimuvate eesmärgistatud protsesside, käsitluste, õppeviiside ja -tegevustena, mis tähistavad igas eas õppija elukestva õppe võimalusi ning õppijate vajadusi (Field, 2006).

Hariduse ja kasvatuse sõnaraamatus on mitteformaalõpe defineeritud omasõnalise termini vabaõpe $e^{3}$ (non-formal learning) kaudu, täpsustades seda kui „vabatahtlikku õpet eri keskkondades väljaspool kooli eesmärgiga end arendada“ (HKS, 2014, vabaõpe). Euroopa Komisjoni dokumentides kasutatakse terminit mitteformaalne haridus (non-formal education) ja sellega seotult elukestva õppimise (lifelong learning) mõistestikku elukestva õppe (lifelong education) kontekstis (Eensaar, 2003). MFÕ diskursuse muutused ilmnevadki üha enam elukestva õppe ja õppimise kontekstis, kus kõneldakse õppijakesksusest, õppija aktiivsest osalemisest õpiprotsessis (Rogers, 2003).

MFÕ põhimõtted ja diskursus on täiskasvanuhariduse ja noorsootöö valdkonnas ning neid reguleerivates dokumentides tähtsal kohal. Kuigi varasemad analüüsid puuduvad, moodustavad siinsele uuringule olulise tausta analüütiline ülevaade täiskasvanuhariduse valdkonna poliitika muutustest Eestis ajavahemikus 1990-2000 (Jõgi, Jääger, Leppänen, \& Rinne, 2008) ning

Haridussõnastikus kasutatud omakeelne termin vabaõpe (HKS, 2014) ei ole poliitikadokumentides kasutust leidnud. Põhjus võib olla liitsõna osises $v a b a$, mis ei viita eesmärgistatud tegevusele. 
ajalooline ülevaade noorsootööst (Taru, Pilve, \& Kaasik, 2015). Eesti keskse haridusstrateegia (EEÕS, 2014) tulemusraamistiku analüüsis jõutakse samuti järeldusele, et strateegias kasutatavad mõisted on vaja selgemalt läbi mõelda (Haaristo, 2016). Sellisel mitmekesisel taustal ja vastuolulises kontekstis oleme sõnastanud järgmise uurimisprobleemi: kuidas konstrueeritakse - kirjeldatakse ja esitatakse - mitteformaalõpet Eesti poliitikadokumentides?

\section{Uurimuse kontseptuaalne raamistik: mitteformaalõppe ja -hariduse ajalooline kujunemine ja tähendus}

Eesti keeles on mõistel haridus eri tähendusi ja kasutusvõimalusi, olenevalt sellest, kas haridust käsitletakse protsessi või tulemusena. Teadustekstides märgib haridus nii protsessi- kui ka tulemusmõistet, mille alusel eristatakse formaalset, mitteformaalset ja informaalset haridust. (Autio, Kuurme, \& Mikser, 2013). Formaalse, mitteformaalse ja informaalse hariduse ja õppe käsitusi on mitmesuguseid, mõistete määratlused on erinevad ja olenevad sellest, mis tekstis, kontekstis ja tähenduses mõisteid kasutatakse. UNESCO hariduspoliitilistes dokumentides on formaalharidust käsitletud kui süsteemset, organiseeritud, struktureeritud ja seadustega reguleeritud protsessi, mille aluseks on standardipõhised õppekavad ja vastavate haridustasemetega seotud eesmärgid (Lockhart, 2016). Omakeelses haridussõnastikus määratletakse formaalharidust institutsionaalselt kui üldharidus-, kutse- ja kõrgkoolides omandatavat haridust (HKS, 2014). Informaalse hariduse definitsioonides on enim seoseid õppimise, õppimisvõimaluste, sotsiaalsete oskuste kujunemise ja indiviidi kogemusega. Näiteks Põhjamaade haridustraditsioonide kohaselt käsitletakse informaalset haridust võrdsust toetava ühiskondliku nähtusena, vabaharidusena, mille eesmärgid on dialoog, koosõppimine, sotsiaalsete ja toimetulekuoskuste täiendamine (Rinne, Kallo, \& Hokka, 2004). Informaalset haridust vaadeldakse ka tegevuste tasandil, näiteks Eesti hariduspoliitilistes dokumentides vabaharidusliku koolitusena ja võimalustena, mis loovad eeldusi isiksuse, loovuse, annete, algatusvõime ja sotsiaalse vastutustunde arenguks (EÕS, 2005). Lisaks kasutatakse informaalse hariduse sünonüümina metafoori eluharidus, et rõhutada informaalse hariduse seoseid õppimisega läbi elu (Märja, Jõgi, \& Lõhmus, 2003).

Lähtudes inglise haridusfilosoofi Petersi ideedest, väidab Jarvis (1998), et hariduse tähenduse käsitlemisel võib tugineda eri kriteeriumidele: 1) hariduse protsess on subjektiivne, alati seotud inimestega ja seetõttu olemuselt humanistlik; 2) haridus mõjutab inimeste heaolu kogu elu jooksul; 3) haridus on objektiivne ja sisaldab õppimisprotsessi, mis on pidev ja elukestev; 4) õppimis- 
protsess võib olla nii planeeritud, spontaanne kui ka juhuslik. Selline käsitlusviis ei sea hariduse tähendusele ja kontekstile piire, vaid osutab haridusele kui õppimisprotsessile, millel võib olla mistahes vorme ja käsitusi ning mis võib aset leida mistahes vanuses, kohas ja eesmärkidel (ibid.).

Alates 1970ndatest, mil loodi pidevhariduse tüpoloogia (Lengrand, 1975), liigitatakse haridust funktsioonide ja formaliseerituse määra järgi formaalseks, mitteformaalseks ja informaalseks (Coombs, Prosser, \& Ahmed, 1973). Formaalharidust nimetati esmahariduseks ning seda defineeriti organiseeritud ja struktureeritud tasemeõppe süsteemina, hiljem ka institutsionaliseeritud, kronoloogiliselt järjestatud ja hierarhiliselt struktureeritud süsteemina (Coombs \& Ahmed, 1974). Uurijate veendumus, et haridust ja hariduse omandamist ei saa piirata ajaliste ja institutsionaalsete raamidega, tõi muutuse ka haridusdiskursusse. Kasutusele võeti termin mitteformaalharidus, võrdsustades selle vormid ja sisu õppimisega (ibid.). Mitteformaalharidust mõisteti kui igasugust väljaspool formaalset haridussüsteemi organiseeritud harivat tegevust, millel on kindlaksmääratud eesmärgid ja mis on suunatud nii lastele kui ka täiskasvanutele, olenemata vanusest, soost ja haridusest (Coombs et al., 1973).

Teadusallikate analüüsi põhjal võib väita, et mõistete mitteformaalne haridus ja mitteformaalõpe kasutamine hariduspoliitilistes tekstides on olnud vajalik mitmel põhjusel. Ühelt poolt seati kahtluse alla formaalhariduse majanduslik jätkusuutlikkus ja mitteformaalõpet nähti alternatiivina formaalharidusele. Teisalt oli mitteformaalharidus strateegiline võimalus, mis täiendab ja laiendab eri sihtrühmade õppimisvajadusi (Shukla, 1983), leevendab ebavõrdsust, mõjutab sotsiaalset heaolu, suurendab sihtrühmade kaasatust ning tagab võrdse juurdepääsu haridusele ja paindlikele haridusprogrammidele (Coombs \& Ahmed, 1974; Fordham, 1993). 1970ndatel oli mitteformaalne haridus ebasoodsamas olukorras ning nõrgemate sihtrühmade õigus ja võimalus, samuti iseloomustas mitteformaalõpet õppekorralduse ja meetodite paindlikkus (Fordham, 1993). Oma olemuselt on MFÕ õppijakeskne, paindlik ja universaalne ning selle eesmärk on tagada vaba juurdepääs haridusele olenemata õppija vanusest ja sotsiaalsest taustast (Delors, 1999; Gustavsson, 2000; Jarvis, 2002). MFÕ universaalsus väljendub kasutatavate käsituste, õppevormide, meetodite ja õppimisviiside variatiivsuses, paindlikkuses ja mitmekesisuses, võimaldades nende laialdast kasutamist ka formaalses hariduses, mitmesugustes õppeolukordades ja eri sihtrühmade korral (Lockhart, 2016; Rogers, 2003).

Coombs jt (1973) seadsid fookusesse MFÕ vastandumise formaalsele haridusele ning haridustegevuse korralduslikkuse ja jätkusuutlikkuse, hiljem räägiti MFÕ alternatiivsetest võimalustest, mis on mõeldud inimestele, kellel puudub juurdepääs formaalsele haridusele (Hoppers, 2006). Samuti määratleti mitteformaalset haridust formaalset haridust täiendava või alter- 
natiivse õppimisvõimalusena (Brennan, 1997). Tingituna formaalse hariduse funktsioonidest ja mõjust, on mitteformaalse hariduse ja õppe arengut saatnud vastuolud ning formaalse hariduse mõjutused, näiteks liigne institutsionaliseeritus, reguleeritus ja standardiseeritus (Jarvis, 2011). Sellised vastuolud, aga ka õppimisvõimaluste variatiivsus ja õppe sisu mitmekesisus on omakorda mõjutanud mõiste käsitusi, MFÕ diskursuse ruumi ja ühtsust (Romi \& Schmida, 2009; van Noy, James, \& Bedley, 2016).

Haridusega seotud diskursuste, sh MFÕ diskursuse muutusi teadustekstides on mõjutanud mitteformaalse hariduse arengule iseloomulikud tendentsid ja haridusfilosoofilised ideed: dialoogilisus, õppijakesksus; juurdepääs, kestus ja jätkuvus; paindlikkus, võimaluste mitmekesisus (Rogers, 2003; van Noy et al., 2016). Muutusi hariduspoliitilistes tekstides on toonud OECD ja Euroopa Liidu majandus- ja hariduspoliitilised suundumused (Aava, 2010; Lockhart, 2016; Rinne et al., 2004), mis väljenduvad mitteformaalse hariduse diskursuste ideoloogilistes muutustes. Nii on 1970ndatel domineerinud mitteformaalõpe kui väljaspool haridussüsteemi toimuva õppe aladiskursus kümnendite jooksul muutunud elukestva õppe aladiskursuseks. Muutuse on tinginud ja selle käiku on mõjutanud Euroopa Liidu hariduspoliitika pöördepunktiks peetud Maastrichti leping (1992) ${ }^{4}$, valge raamat ${ }^{5}$ (1995) ning Lissaboni leping ${ }^{6}(2000)$ (vt ka Aava, 2010).

Kriitiline lähenemine MFÕ tähenduste ja tavade analüüsimisele on olnud aktuaalne täiskasvanuhariduse muutusi ja täiskasvanute õppimist kirjeldavates uurimustes (Brookfield, 1986; Kleis, Lang, Mietus, \& Tiapula, 1973; Knowles, 1970), hiljem ka noorsootöö uurimustes (Kiilakoski \& Kivijärvi, 2015; Norqvist \& Leffler, 2017). Formaal- ja mitteformaalõppes kasutatakse üha enam mitteformaalse, informaalse ja formaalse hariduse funktsioone ja käsitusi ning kombineeritakse meetodeid. Seetôttu on ka Colley jt (2003) seisukohal, et formaal- ja mitteformaalõppe eristamine on põhjendamatu. Mõlema õppe komponendid (nt keskkond, meetodid, hindamine) on õppeprotsessis seostatud (ibid.).

Van Noy jt (2016) kuuesaja teaduspublikatsiooni analüüsil põhinevast uuringust ilmneb, et MFÕ definitsioonid on variatiivsed ja kohati kattuvad, sisaldades kolme tähendustasandit: indiviidid, institutsioonid ja hariduspoliitika. Tähendusi luuakse eri kontekstides, mis jagunevad informaalseks ja kogukondlikuks õppimiseks; täiskasvanute ja noorte õppimiseks ning

Maastrichti ehk Euroopa Liidu leping, jõustunud 01.11.1993.

Euroopa noortepoliitika valge raamat. Lõplik versioon. Brüssel, 21.11.2001.

Lissaboni leping, jõustunud 01.12.2009. 
tööalaseks ja elukestvaks õppimiseks. Peale nimetatute avaldavad tähendustele mõju ka õppimise koht, sisu ja eesmärgid (ibid.).

MFÕ terminite kasutuselevõtt täiskasvanuhariduse ja noorsootöö valdkonnas on seotud eelkõige rahvusvaheliste programmide ning Euroopa Liidu vastavate strateegiliste dokumentidega. Maastrichti lepinguga muudeti 1990ndatel Euroopa Liidu hariduspoliitika suundumusi, seades fookusesse sidusrühmade koostöö (Ertl, 2006; Naumanen, Leppänen, \& Rinne, 2008). MFÕ diskursuste kujunemisel Euroopa Liidu hariduspoliitika dokumentides võib eristada kolme ajalist etappi: Maastrichti lepingu eelset (1957-1992), Maastrichti lepingu järgset (1992-1999) ja Lissaboni strateegia ${ }^{7}$ järgset etappi (2000-2012), kus MFÕ diskursuse muutus on olnud ideoloogiline ja toimunud Euroopa Liidu hariduspoliitiliste mõjutuste taustal.

Euroopa Liidu hariduspoliitilistes dokumentides on MFÕ diskursused oluliselt muutunud. Kui 1960.-1970. aastatel oli mitteformaalse hariduse diskursuseks väljaspool formaalse hariduse süsteemi toimuva õppe diskursus, siis alates 1993. aastast on see asendunud elukestva õppe diskursusega. Diskursuse muutused peegeldavad, kuidas poliitikakujundajate ideoloogiliste valikute kaudu jõutakse haridusfilosoofiliste ideaalide ja väärtuste juurest mitteformaalse hariduseni kui iga inimese võimaluse ja õiguseni õppida (Fordham, 1993; Lockhart, 2016; Rogers, 2003).

Euroopa Liiduga liitumisel võeti Eesti poliitikakujundamises üle asjaomane mõistestik. 2000ndate uues haridusstrateegias (EEÕS, 2014) käsitletakse haridust juba Euroopa Liidu normdokumentidele omases paradigmas. Varasem Eesti arengut suunavate hariduspoliitiliste dokumentide analüüs (Aava, 2010) on osutanud domineerivatele diskursiivsetele strateegiatele poliitikadokumentides ja nende mõjule Eesti ühiskonnas, seepärast keskendume siinkohal just poliitikadokumentide analüüsile.

\section{Uurimuse metodoloogiline raamistik}

Uurimuses kasutame kriitilise diskursuseanalüüsi (KDA) ja poliitikaradade analüüsi (PRA) meetodi kombinatsiooni, lähtudes sotsiaalse konstruktsionismi ideest. Selle kohaselt ei ole sotsiaalne reaalsus midagi etteantut, vaid ühiskondlike kokkulepete ja tõekspidamiste konstrueeritud kogum, mis on mõjutatud nii ajalooliselt, kultuuriliselt, sotsiaalselt kui ka keeleliselt (Berger \& Luckmann, 2018; Gergen, 2009; Raud, 2013). Ideoloogilisi valikuid ja ühiskonnarühmade võimusuhteid väljendavad kokkulepped kujundavad ühis-

Lissaboni strateegia tegevuskavades „It's never too late to learn“ (2006) ja „It's always a good time to learn“ (2007) keskendutakse täiskasvanuhariduse poliitikale ja praktikale Euroopa Liidus. 
konnas toimivaid diskursusi (Foucault, 2005). Nende mõtestamisel on kesksel kohal viis, kuidas keelt kasutatakse, juhindudes põhimõttest, et keel peegeldab ja konstrueerib ${ }^{8}$ sotsiaalset maailma ning sealseid nähtusi (Fairclough, 2001; Hacking, 1999). Seega on diskursus süsteem, kommunikatiivne sündmus, mille korral luuakse keele kaudu sotsiaalset tegelikkust (Fairclough, 2010). Keelekasutus ise ei ole neutraalne, vaid võimu kallutatud (Fairclough, 2001, 2010). Eriti selge on võimu roll diskursuse konstrueerimises poliitikadokumentide puhul, mille kaudu legitimeeritakse ja taastoodetakse ühiskonna ideoloogilisi tõekspidamisi.

Võttes aluseks nii sotsiaalkonstruktsionistliku paradigma kui ka kriitilise maailmakäsituse, kaardistasime PRA meetodi abil maastikku, millel poliitika kulgeb, keskendudes MFÕ tähendusi konstrueerivatele diskursustele (vt Cort, 2014; Holford \& McKenzie, 2013). Maastikena vaatleme uurimuses valdkondlikke poliitika raamdokumente, mis sisaldavad MFÕ mõistet ja loovad jagatud mõistevälja, mille raamistikus poliitikat kujundatakse ja rakendatakse. Valdkondlikest poliitikadokumentidest moodustasime kronoloogilised poliitikarajad. Seejuures võimaldas PRA meetod käsitleda, kuidas MFÕ mõiste varieerub valdkondlike poliitikadokumentide loojate kollektiivselt jagatud diskursuseruumis. Osati täidab konstruktsionism siinses uurimuses ka mõtestamise funktsiooni - uuringu tulemuste esitamisel osutame ka tähendustele ja nende konstrueerimise kontekstile (vt Hacking, 1999). Kuna poliitikadokumendid võivad väljendada ühiskondliku kokkuleppe käigus kujunenud jagatud tähendust, kasutame selle mõistmiseks PRA meetodi kõrval ka KDAd, mis võimaldab selgitada, milliseid MFÕ tähendusi keele abil konstrueeritakse ja kinnistatakse, ning osutada diskursuste kaudu esile kerkivatele sotsiaalsetele suhetele ja ühiskondlikele tähendustele.

\section{Uurimismaterjal ja uuring}

Analüüsi fookuses on Eesti poliitikadokumendid aastatest 2000-2018. Tekstide esmane valim kujunes 78 riiklikust strateegilisest ja haridusvaldkonna õigusloome dokumendist ehk poliitikadokumendist. Dokumentide kogumiseks kasutasime Riigi Teataja veebilehel otsisõna mitteformaal (tulemuseks kaks dokumenti: kutse- ja kõrgharidusstandard). Dokumentide esmast valimit täiendasime Vabariigi Valitsuse arengukavade veebilehel ${ }^{9}$ nimetatud

8 Keelendi konstrueerima (to construct) asemel kasutatakse ka sõna tõlgitsema (to construe), mis viitab selgemini teksti loomise mentaalsele poolele (vt Halliday, 2005). Kasutame artiklis siiski sõna konstrueerima, et järgida sotsiaalkonstruktsionismile omast terminitarvitust.

9 Vabariigi Valitsuse arengukavade veebileht (s. $a$.); https://www.valitsus.ee/et/eesmargid-tegevused/arengukavad. 
47 poliitikadokumendiga, Haridus- ja Teadusministeeriumi veebilehe ${ }^{10}$ õigusloome vahelehel loetletud 20 seadusega ning täiskasvanuhariduse ja noortevaldkonna alalehtedel toodud üheksa õigusaktiga. Lõpliku valimi moodustamiseks kasutasime nende dokumentide täistekstides tunnusepõhist otsingut otsisõnadega mitteformaalõpe, mitteformaalne õpe, vabaõpe, mitteformaalharidus, mitteformaalne haridus ja vabaharidus. Esmasesse valimisse kuulunud poliitikatekstidest (loodud aastatel 2000-2018) sisaldas neid otsisõnu 23 dokumenti, millest moodustasime tekstide lõpliku valimi ja mille põhjal analüüsisime MFÕ tähendusi. Dokumentide lõpliku valimi moodustasid kaks Euroopa tasandi raamdokumenti, kaks seadust (keeleseadus, täiskasvanute koolituse seadus), kaks Vabariigi Valitsuse määrusega kinnitatud standardit (kutse- ja kõrgharidusstandard), 16 riiklikku strateegiadokumenti ning üks programmiline dokument.

Analüüsiprotsess koosnes viiest etapist. Protsessi usaldusväärsuse ja tulemuste täpsuse suurendamiseks kasutasime uurijate triangulatsiooni (Cohen, Manion, \& Morrison, 2000). Esmalt jagasime dokumendid omavahel ära, seejärel kodeeris igaüks iseseisvalt eri valdkondade dokumente. Tulemuste usaldusväärsust kontrollisime uurijate dialoogi kaudu (vt Åkerlind, 2005). Korduvate arutelude ja diskussioonide käigus jõudsime tulemuste ja tõlgenduste suhtes konsensusele. KDA puhul võtsime aluseks Faircloughi (2001) kolmeastmelisest diskursusemudelist tuleneva analüüsidisaini: 1) otsisime ja kirjeldasime tekstide keelevalikuid; 2) tõlgendasime nende keelevalikute suhet kontekstiga ja 3) selgitasime tekstide ja ühiskondliku konteksti suhteid. Arendasime seda mudelit edasi, lisades analüüsiprotsessi kaks etappi (vt kirjeldus allpool).

Esimeses etapis selgitasime välja dokumentide metainfo (dokumendi loomise aeg, päritolu, otstarve, kehtivus ja maht) ning analüüsisime MFÕ mõistestiku kasutamist poliitikadokumentides neljast aspektist: MFÕ terminiga seotud keelevalikud ja kontekst, MFÕ mõiste tähendust kandvad keelevalikud ja kontekst, teksti struktuur ning diskursuse konstrueerimise viis. Terminitega MFH ja MFÕ seotud keelevalikute ning nende kasutuskonteksti kaudu selgitasime fraase ja lauseid, kus mõistestikku kasutati. Seevastu mõistete MFH ja MFÕ tähendust kandvad keelevalikud võimaldasid avada võtmesõnu ja kasutuskonteksti. Terminite paiknemine teksti struktuuris väljendus nii sõna esinemises kui ka selles, kellele oli tegevus suunatud (kellele omistatakse subjektsus) ning kes vastutab tegevuse eest (kellele omistatakse agentsus). Esimese etapi järel tehtud kokkuvõtetest selgus, et MFÕd konstrueeritakse kõige enam

10 Haridus- ja Teadusministeeriumi veebileht (s. a.); https://www.hm.ee/et/eesmargid-tegevused/oigusloome. 
haridusvaldkonna poliitikadokumentides, st elukestva õppe ja noortevaldkonna dokumentides.

Teises etapis võrdlesime tulemusi dokumentide kaupa. Selgus, et aastatel 2000-2018 nimetati MFÕd kõige enam elukestva õppe ja noortevaldkonna dokumentides, lisaks sisaldusid MFÕ otsisõnad teiste valdkondade dokumentides. Eeldades, et hilisemate dokumentide loomisel on võetud aluseks varasemad (või suhestuti nendega), selgitasime kronoloogia alusel välja elukestva õppe ja noortevaldkonda kirjeldavad poliitikadokumentide rajad (joonis 1).

\begin{tabular}{|c|c|c|}
\hline $\begin{array}{l}\text { Noortevaldkonna } \\
\text { dokumentide rada }\end{array}$ & $\begin{array}{c}\text { Elukestva õppe valdkonna } \\
\text { dokumentide rada }\end{array}$ & \\
\hline $\begin{array}{l}\text { Euroopa Komisjoni valge raamat } \\
\text { „Uus hoog Euroopa noortele” (2001) }\end{array}$ & $\begin{array}{l}\text { Elukestva õppe strateegia 2005-2008 } \\
\qquad(2005)\end{array}$ & $\begin{array}{r}2001- \\
2005\end{array}$ \\
\hline $\begin{array}{c}\text { Noorsootöö strateegia 2006-2013 } \\
\text { (2006) }\end{array}$ & $\begin{array}{l}\text { ELi nõukogu strateegiline raamistik } \\
\text { „Haridus ja koolitus } 2020 \text { (2009) }\end{array}$ & $\begin{array}{r}2006- \\
2010\end{array}$ \\
\hline \multirow[t]{3}{*}{$\begin{array}{l}\text { Noortevaldkonna arengukava } \\
2014-2020 \text { (2013) }\end{array}$} & $\begin{array}{l}\text { Elukestva õppe strateegia } 2020 \\
\text { (2014) }\end{array}$ & \multirow{2}{*}{$\begin{array}{r}2010- \\
2015\end{array}$} \\
\hline & $\begin{array}{l}\text { Täiskasvanute koolituse seadus } \\
\text { (1993/2015) }\end{array}$ & \\
\hline & $\begin{array}{l}\text { Täiskasvanuhariduse programm } \\
\text { 2018-2021 (2016) }\end{array}$ & $2016+$ \\
\hline
\end{tabular}

Joonis 1. Mitteformaalõpet konstrueerivate poliitikadokumentide valdkondlikud ja kronoloogilised rajad elukestva õppe ja noortevaldkonna dokumentide näitel

Teised lõplikku valimisse kuuluvad poliitikadokumendid jagasime valdkonna alusel tinglikult kultuuri, sotsiaalse heaolu, majanduskasvu ja kliima poliitikaradadesse (joonis 2). Analüüsitud dokumendid on välja antud 18 aasta jooksul. MFÕd sisaldanud noortepoliitika dokumentide raja pikkus on 13 aastat, elukestva õppe raja pikkus 10 aastat ja heaoluvaldkonna raja pikkus 11 aastat, seevastu kultuuri- ja majandusvaldkonna rada on neli ning kliimavaldkonna rada kaks aastat pikk. Sellest järeldame, et MFÕ on teiste valdkondade poliitikakujundajate jaoks aktuaalsemaks muutunud viimasel kümnendil, v.a mitut valdkonda reguleeriv alusdokument „Säästev Eesti 21“(koostatud 2005. aastal). 


\begin{tabular}{|c|c|c|c|}
\hline Kultuur & Heaolu & Majandus & Kliima \\
\hline $\begin{array}{l}\text { Eesti keele } \\
\text { arengukava (2010) }\end{array}$ & $\begin{array}{l}\text { „Säästev Eesti 21" } \\
\text { (2005) }\end{array}$ & & \\
\hline \multirow{4}{*}{$\begin{array}{l}\text { Keeleseadus (2011) } \\
\text { „Lõimuv Eesti“ (2012) } \\
\text { Kultuuripoliitika } \\
\text { põhialused (2013) }\end{array}$} & $\begin{array}{l}\text { Laste ja perede } \\
\text { arengukava (2011) }\end{array}$ & $\begin{array}{l}\text { Infoühiskonna } \\
\text { arengukava (2013) }\end{array}$ & \\
\hline & $\begin{array}{l}\text { Kodanikuühiskonna } \\
\text { arengukava (2015) }\end{array}$ & $\begin{array}{l}\text { Regionaalarengu } \\
\text { strateegia (2014) }\end{array}$ & \\
\hline & $\begin{array}{l}\text { Heaolu arengukava } \\
\text { (2016) }\end{array}$ & $\begin{array}{l}\text { Konkurentsivõime } \\
\text { kava (2017) }\end{array}$ & $\begin{array}{l}\text { Kliimamuutustega } \\
\text { kohanemise } \\
\text { arengukava (2016) }\end{array}$ \\
\hline & & & $\begin{array}{l}\text { Kliimapoliitika } \\
\text { põhialused (2017) }\end{array}$ \\
\hline
\end{tabular}

Joonis 2. Mitteformaalõpet konstrueerivate poliitikadokumentide rajad valdkondade kaupa: kultuuri-, heaolu-, majandus- ja kliimapoliitika valdkonna dokumendid

Kolmandas etapis analüüsisime MFÕ tähenduste poliitikaraamistuse esiletoomiseks, kuidas on selle koostajad kirjeldanud järgmisi dokumentides esile kerkinud teemasid:

1) mis on MFH ja MFÕ peamine funktsioon, st kuidas on sõnastatud eesmärk;

2) kes peaks MFHs ja MFÕs osalema, st kes on otsene sihtrühm;

3) kes peaks MFHs ja MFÕs osalemist toetama, st kes on vastutaja;

4) millised on MFH ja MFÕ eriomased jooned, kohad ja viisid.

Ilmnenud tunnused kodeerisime induktiivselt, koondades need neljandas etapis sarnasuse põhjal kategooriateks. Rühmitamisel lähtusime hinnangust nende läheduse, vastandlikkuse või kattuvuse kohta. Analüüsi viiendas etapis eristasime poliitikakujundajate aktualiseeritud diskursusi, avades neid selle kaudu, mis keelevalikuid on MFH ja MFÕ tähenduse esitamisel tehtud. Süstematiseerimise käigus ilmnes neli diskursust, mille nimetasime keskkonna-, eristumis-, kaasamis- ja süsteemidiskursuseks. Neist igaüks jagunes omakorda kaheks aladiskursuseks. Lisaks eristus viiendana tunnustamisdiskursus, mis jagunes kaheks aladiskursuseks. Need aladiskursused esinesid nelja ülejäänud diskursuse kõigis aladiskursustes, millest igaühel on sisuline ja formaalne dimensioon. 


\section{Mitteformaalõppe diskursused}

Diskursuseanalüüsi tulemused esitame diskursuste ja nende aladiskursuste kaupa (tabel 1), arvestades diskursuste esinemist ajajoonel poliitikaradadena. Diskursuse konstruktsioone ilmestavad ja põhjendavad tekstinäited.

Tabel 1. Poliitikadokumentides eristatud mitteformaalõppe diskursused ja nende aladiskursused

\begin{tabular}{lll}
\hline \multicolumn{1}{c}{ Diskursused } & \multicolumn{2}{c}{ Aladiskursused } \\
\hline a. Keskkonnadiskursus & $\begin{array}{l}\text { a1. MFÕ toimub mitte- } \\
\text { formaalses keskkonnas }\end{array}$ & $\begin{array}{l}\text { a2. MFÕ tegevused loovad } \\
\text { MFÕ keskkonna }\end{array}$ \\
\hline b. Eristumisdiskursus & $\begin{array}{l}\text { b1. MFÕ on sarnane teiste } \\
\text { õppimisviisidega }\end{array}$ & $\begin{array}{l}\text { b2. MFÕ eristub teistest } \\
\text { õppimisviisidest }\end{array}$ \\
\hline c. Kaasamisdiskursus & c1. MFÕ on kõigile & $\begin{array}{l}\text { c2. MFÕ kaasab eksplitsiitselt } \\
\text { eri sihtrühmi }\end{array}$ \\
\hline d. Süsteemidiskursus & d1. MFÕ on süsteemi osa & d2. MFÕ on süsteem \\
\hline e. Tunnustamisdiskursus & e1. MFÕd tunnustatakse & e2. MFÕd tunnustatakse \\
& sisuliselt & formaalselt
\end{tabular}

Esitame kõigi diskursuste ja aladiskursuste kirjeldused, liikudes detailsema juurest üldisema poole, ning toome näiteid dokumentidest, mille loomisel tehtud tekstilised valikud osutavad konkreetsetele diskursustele ${ }^{11}$. Avame ka iga diskursuse tähendust poliitikakujundajate ideoloogiliste valikute kontekstis.

Keskkonnadiskursus rõhutab MFÕle eriomast. Nii elukestva õppe kui ka noortevaldkonna raja dokumentide loojad väljendavad MFÕ puhul ootust, et see aitab luua õppija arengut toetavat õpikeskkonda ja edendada vabatahtlikkust. Eri valdkondade poliitikakujundajad osutavad, et tegevus ja keskkond on MFÕ lahutamatud osad. Aladiskursus MFÕ toimub mitteformaalses keskkonnas (a1) kirjeldab MFÕ mõistes sisalduvat eitust ja sedakaudu vastandumist formaalsele keskkonnale, mis võib olla põhjus, miks täpsemaid tingimusi pole kirjeldatud (näide 1).

(1) ... soodustatakse noorte eesti keele õpet mitteformaalses keskkonnas. $(\mathrm{Ku}$ _A_2012)

Mitteformaalset keskkonda on eraldi nimetatud vaid seoses keeleõppe võimalustega MFÕ kontekstis. Füüsilise keskkonna loomise tingimused tulevad esile

11 Näiteks E_S_2005 tähistab elukestva õppe valdkondliku raja strateegiadokumenti aastast 2005; vt dokumentide tähiseid lisast. 
üksnes regionaalarengustrateegias ning ligipääsetavus erivajadustega laste jaoks laste ja perede arengukavas. Asjaolu, et muid keskkonnatingimusi ei ole dokumentides kirjeldatud, võib osutada MFÕ keskkondade suurele variatiivsusele.

Aladiskursuse MFÕ tegevused loovad MFÕ keskkonna (a2) raames on mõne poliitikadokumendi loojad kirjeldanud mitteformaalseid tegevusi osana elukestvast õppest, määrates tegevuste elluviimiseks kindlaks tingimused: eesmärgistatuse, kestuse, õppijakesksuse (näide 2). Olulise MFÕ tegevuste tunnustena on nimetatud tahtlikkust ja sihipärasust, MFH puhul kodanikuhariduse tegevusi ja programme, mis viiakse ellu koostöös koolide ja kodanikuühendustega (näide 3).

(2) suurendatakse Eesti elanikkonna võimalusi ja motivatsiooni osalemiseks nii formaalses, mitteformaalses kui ka informaalses õppetegevuses ... (E_S_2005)

(3) ... osalemist ja kaasamist toetavate hoiakute kujundamisele koostöös kodanikuühendustega, st mitteformaalhariduslike programmide ulatuse ja mõju kasvatamisele ... (H_A_2015)

Kui MFÕ mõiste puhul on nimetatud eesmärgistatust, tegevusi, temaatikat ja elluviijaid, siis dokumentide autorid on MFH mõiste esitanud üldistatumalt, hõlmates pigem haridusele universaalselt omaseid aspekte.

Eristumisdiskursuses antakse MFHle formaalharidusega võrdne positsioon ning toetav roll soovitud eesmärkide saavutamisel, pidades silmas nii koolitusel osalejat kui ka koolituse pakkujat. MFÕd on määratletud formaalsest õppest väljaspool või, vastupidi, sellega samal tasandil olevana. Dokumentide loojad näivad rõhutavat, et MFÕ on õppija jaoks võrdväärne taseme- ja täiendkoolitusega ning õpitulemused võivad olla saavutatud nii formaalse, mitteformaalse kui ka informaalse õppimise teel. Eristamine (samal ajal võrdsustamisega) on suunatud koolituste pakkujatele ja õppijatele, et rõhutada eri formaalsusastmes toimuva õppe võrdset aktsepteerimist. Ühtlasi antakse dokumentides suuniseid MFÕ teel omandatud teadmiste ja oskuste arvestamiseks formaalõppes. Aladiskursus MFÕ on sarnane teiste õppimisviisidega (b1) näitab MFÕ sarnasust formaal- ja informaalõppega teises vormis õppetegevuste kaudu (näide 4). Aladiskursus MFÕ eristub teistest öppimisviisidest (b2) ilmneb kõige enam MFÕ osaliste, sh sihtrühmade määratluses (näide 5).

(4) [VÕTA] eesmärk on: 2) võimaldada haridustasemetest koosnevas haridussüsteemis õppimise (formaalharidus), muu organiseeritud õppetegevuse (mitteformaalne haridus) ja erialase töökogemuse kaudu ning igapäevase tegevuse ja vaba aja raames õppimise (informaalne haridus) tulemusi lugeda samaväärseks. (E_Õ_2008/2018) 
(5) Lisaks on noorte ees seisvate ülesannetega toimetuleku toetamiseks oluline roll mitteformaalsel õppel ja noorsootööl. (M_A_2017)

Lisaks eristati sihtrühmade alusel eesti- ja muukeelseid inimesi, noori töötuid ja töötavaid inimesi, õppivaid ja mitteõppivaid täiskasvanuid.

Kaasamisdiskursus luuakse selle kaudu, keda konkreetse poliitikadokumendi valdkonnas konstrueeritakse sihtrühmana. Aladiskursuses MFÕ on kõigile (c1) eristatakse pigem tugevaid, aktiivseid MFÕ osalejaid: kõik inimesed, kogu elanikkond, lihtsalt täiskasvanud (tööealine elanikkond) või noored. Eraldi sihtrühma moodustavad óppijad: nii kooliõpilased kui ka elukestvas õppes juba osalevad inimesed. Poliitikakujundajad on dokumentides esile toonud MFÕ kui kõigile avatud võimaluse vabatahtlikuks õppeks (näide 6) või seostanud selle kultuuridevahelise õppimisega (näide 7).

(6) Mitteformaalne õpe on eesmärgistatud nagu formaalõpegi, kuid vabatahtlik. (E_S_2005)

(7) kultuuridevaheline õppimine on muutunud uueks väljakutseks ja võimaluseks noorte mitteformaalse hariduse teel. (N_S_2006)

MFÕ kui kaasamine avaldub omaette väärtusena, mida taotletakse MFÕ programmide mõju kasvatamiseks (näide 8).

(8) osalemist ja kaasamist toetavate hoiakute kujundamisele koostöös kodanikuühendustega, st mitteformaalhariduslike programmide ulatuse ja mõju kasvatamisele. (H_A_2015)

MFÕ kontekstis on oluline tagada õppijatele huvide- ja võimetekohane õpe, toetada nende toimetulekut haridussüsteemis (näide 9), võimaldada tulemuste ülekandmist ning rikastada nende õpikogemust.

(9) Sarnane arusaam õpikäsitusest võimaldab teha senisest tõhusamat koostööd ning loob vajaliku fooni vähem motiveeritud täiskasvanute õppesse toomiseks ja õppes püsimiseks. (E_P_2016)

Neile, kes veel ei õpi, esitletakse MFÕd kui võimalust muutuda, olla ühiskonna sotsiaalsetes rollides väärtuslikum (lapsevanem, kodanik, töötaja), juhul kui õppimisvõimalust ei jäeta kasutamata.

Aladiskursus MFÕ kaasab eksplitsiitselt eri sihtrühmi (c2) avaldus sihtrühmade nimetamise kaudu. Dokumentides viidati nõrgematele rühmadele, nt eri emakeelega inimesed, töötud, riskinoored (näited 10, 11). Käskivas kõneviisis ja vastutajat nimetamata (tuleb parandada, arendada) osutati tegevustele, mida peaks nende sihtrühmade olukorra parandamiseks ette võtma. 
(10) eesti keelest erineva emakeelega elanike konkurentsivõime tugevdamiseks ja töövõimaluste suurendamiseks ... tuleb parandada nii formaalsete keelekursuste kui ka veebipõhiste kursuste kättesaadavust, arendada mitteformaalseid eesti keele õppe võimalusi ... (M_A_2017)

(11) Projekti eesmärgiks on teha huvihariduse ja -tegevuse võimalused riskinoortele kättesaadavamaks. (N_A_2013)

MFÕ eesmärgina rõhutasid poliitikadokumentide loojad individuaalset enesearengut, kuid diskursuse lähem avamine osutab sellele, et heaolu, elukvaliteet, hea enesetunne ja soovide täitumine pigem kaasnevad tööalaste teadmiste ja tööalase konkurentsivõime kasvuga. Õppimise ja enesearengu subjektiks olemist peavad poliitikakujundajad vähem oluliseks. Enese aktualiseerimine kodanikuna ja edukus töötajana kui MFÕ eesmärgid tulevad analüüsitud dokumentides selgelt esile teiste valdkondlike poliitikadokumentide radadel, kuid mitte elukestva õppe ja noortepoliitika radadel.

Süsteemidiskursuses eristuvad kaks aladiskursust. Aladiskursust MFÕ on süsteemi osa ( $\mathrm{d} 1$ ) on poliitikakujundajad dokumentides konstrueerinud mitmel moel, nt elukestva õppe või täiskasvanuhariduse osana (näide 12), professionaalse arengu, hariduse, elulaadi, noorsootöö osana (näide 13) või ühe noortega arvestamise valdkonnana (näide 14).

(12) Täiskasvanuharidus on tasemeharidus, vabaharidus ning tööalane täiendkoolitus koos. (E_Õ_1993/2015)

(13) Noorsootöö teostamise keskkond on noorte poolt aktsepteeritav ning soodustab mitteformaalset ja informaalset õppimist. (N_S_2006)

(14) Prioriteetsed valdkonnad, kus noortega arvestada, on haridus, elukestev õpe, liikuvus, tööhõive, sotsiaalne lõimumine, rassism, võõraviha. (N_EL_2001)

Aladiskursuse MFÕ on süsteem (d2) korral on MFÕ iseseisev tervik, mida on võimalik seostada tööga (näited 15,16 ) või lõimida formaalharidusega (näide 17). Samuti kirjeldati MFÕd kui eraldi tervikut väljaspool formaalharidust koos vabahariduse kui süsteemiga.

(15) Sõltuvalt eesmärgist on koolitus käesoleva seaduse kohaselt: 1) tasemekoolitus; 2) tööalane koolitus; 3 ) vabahariduslik koolitus. (E_Õ_1993) 
(16) Täiskasvanute koolitus jaguneb tasemeõppeks ja täienduskoolituseks. (E_Õ_2015)

(17) Huvihariduse lõimimine formaalharidusega ning õppetöö läbiviimine väljaspool koolikeskkonda. (E_S_2014)

MFÕd käsitletakse poliitikadokumentides vahel eraldiseisva süsteemina, vahel osana suuremast süsteemist, kuid enamasti on MFÕ kontekst selgelt esitamata. See muudab keeruliseks ülekanded poliitikavaldkondade vahel: eri valdkondade poliitikakujundajad võivad sama mõistet kasutades pidada silmas eri tähendusi.

Tunnustamisdiskursuses eristuvad kaks aladiskursust. MFÕ aladiskursuse MFÕd tunnustatakse sisuliselt (e1) raames konstrueeritakse MFÕd kui teiste tegevustega samaväärset ja täiendavat viisi mingite eesmärkide taotlemisel. MFÕd kirjeldatakse teiste õppevormidega võrdväärsena, mis toetab valdkondlike eesmärkide saavutamist, sh elukestva õppe, noorte-, heaolu-, kultuuri-, majandus- ja kliimavaldkonnas. Seevastu aladiskursuse MFÕd tunnustatakse formaalselt (e2) raames pööravad poliitikakujundajad tähelepanu MFÕ tõendamisele, legitimeerides MFÕd õpitulemuste kirjeldamise ja arvestamise kaudu, nt tasemeõppe tegevusi asendavana. Seejuures on tunnustamisdiskursus kogu MFÕ tähendusväljade kaardistamisel olulisim, kuna see esineb kõigis eelkirjeldatud diskursustes.

Kaasamisdiskursuse korral sedastab poliitikakujundaja, et MFÕ tegevusi (nt kutsealane praktika ja projektõpe) tuleb tunnustada legitiimse osana tasemeoppest (näide 18), nagu on valdkondlikes õigusaktides, sh kõrgharidus- ja kutsestandardis, ka sätestatud. Lisaks võib MFÕ keskkonnas toimuvat õppimist pidada tööalase arengu seisukohalt väärtuslikuks või tunnustada seda tasemeõppe läbimisel (näide 19).

(18) Õpingud on õpilase tegevus õppe- ja töökeskkonnas õppekavaga seatud eesmärkide ja õpiväljundite saavutamiseks (E_Õ_2013/2018).

(19) võimaldada lugeda tasemehariduses (formaalharidus) õpitut, muu organiseeritud õppetegevuse (mitteformaalne haridus) ja töökogemuse kaudu (E_Õ_2013/2018).

Eristumisdiskursuses sisaldub püüd tunnustada MFÕd unikaalse õpikogemuse ja õppevormina. MFÕ liigse raamistamise ja formaliseerimise tõttu võib aga MFÕ eripära kaduda või MFÕ võib saada formaalõppe osaks. Samuti on oht, et õppevormid muutuvad liiga ühetaoliseks. 
Kaasamisdiskursuses sõnastatakse MFÕ võimalusena saada kasu ja panustada kogukonna või tööturu toimimisse. MFÕ on orienteeritud võimaluste loomisele, et teadvustada, märgata ja tunnustada spetsiifiliste sihtrühmade vajadusi ning luua neile sobivaid võimalusi (näide 20). Rõhutatakse, et aktiivselt MFÕ tegevustesse kaasatavad keerulisemad ja vähem motiveeritud sihtrühmad, nt madalama haridustaseme ja vähemate oskustega täiskasvanud, võiksid säilitada agentsuse nii õppimisotsuse tegemisel kui ka õppimisel (näide 21). Selline lähenemisviis võib märgistada peale osalejate ka kõrvalejääjad ning MFÕst võib saada sotsiaalse kontrolli mehhanism. Seetõttu on oluline tunnustada kõigi õppijate vajadusi ja õigusi, sh õigust õppimisest kõrvale jääda.

(20) Eesti elukestva õppe süsteemi arengu eesmärgiks on kõigile Eesti inimestele nende vajadustele ning võimetele vastavate õpivõimaluste loomine. (E_S_2014)

(21) Madalama haridustaseme ja oskustega täiskasvanute toomine tasemeõppesse ja täienduskoolitusse. (E_P_2016)

Süsteemidiskursuse raames ehk MFÕ käsitlemisel muu süsteemi osana kirjeldavad poliitikakujundajad MFÕ rolle süsteemis, selle võrdset tunnustamist, nt kvaliteedist lähtudes. MFÕ tunnustamise tingimus on selle kirjeldamine süsteemis (näited 22, 23).

(22) Täiskasvanute õppimisvõimaluste avardamiseks on kiiresti vaja välja töötada süsteem tööalase ja vabaharidusliku õppe ning töökogemuste arvestamiseks tasemeõppes. (H_S_2005)

(23) Strateegiliseks hariduspoliitiliseks väljakutseks on elukestva õppe süsteemi loomine ja selle kvaliteedi tagamine. (E_S_2014)

Tunnustamisdiskursusest ilmnevad kõige selgemalt võimalikud edasised muutused MFÕ sisu ja vormi sotsiaalsel konstrueerimisel. Poliitikadokumentide keelekasutuse alusel eristatud diskursused väljendavad ühiskonnaliikmete, huvirühmade ja võimukandjate läbirääkimiste või nende puudumise tulemusi. Domineerima jäänud ideoloogilised suundumused loovad pidevalt diskursiivset ruumi uuteks valikuteks. Praktikud saavad tähendusi taasluua või neis kahelda, aidates poliitikakujundajatel sama sõnavara ja keele abil luua üheselt mõistetava sotsiaalse tähendusega MFÕ sisu. 


\section{Kokkuvõte}

Artiklis on esitatud Eesti ühiskonna arengut suunavates poliitikadokumentides ilmnenud diskursused, mis konstrueerivad MFÕ tähendusi, ja ajalised poliitikarajad, mis jagunevad kuueks valdkondlikuks rajaks. Neist enam ja pikema aja jooksul on MFÕd käsitletud noortepoliitika ja elukestva õppe raja dokumentides, kuid ka heaolu-, kultuuri-, majandus- ja kliimapoliitika raamdokumentide loojad on oma sõnumit konstrueerinud MFÕ aladiskursuste kaudu ning mõjutanud sellega MFÕ diskursuse muutumist.

MFÕd käsitletakse poliitikadokumentides pigem instrumentaalse või institutsionaalsena. Eesti hariduspoliitika peamises strateegias on MFÕd määratletud formaalharidusele vastandumise kaudu: „Mitteformaalne õpe leiab aset väljapool kooli ning on ette võetud teadlikult eesmärgiga end arendada“ (EEÕS, 2014, lk 23). MFÕ tähendus on kitsas ja kogu mõiste sisu see ei ava: diskursus õpe väljaspool kooli oli iseloomulik 1970. aastate Euroopa Liidu hariduspoliitika dokumentidele ja peaks nüüdisajal olema avardunud. Definitsioon ise osutab mõiste ühele sisuaspektile, arvestamata teisi tähendusi ja piirates nii mõiste võimalike kasutusalade ulatust. MFÕ on eesmärgistatud formaalõppe kaudu ja seda ka rõhutatakse: „Mitteformaalne õpe on eesmärgistatud nagu formaalõpegi, kuid vabatahtlik" (EEÕS, 2014, lk 23). Sellise sõnastuse taust ja põhjused võivad tugineda arusaamale MFÕst kui mitteformaalse hariduse osast, mis oli iseloomulik 1960ndate ingliskeelses teaduskirjanduses avaldunud MFÕ diskursusele, kui MFÕd käsitleti formaalharidust asendava võimalusena riikides, kus puudus formaalhariduse süsteem (Lockhart, 2016), ja MFÕ oli veel kontseptualiseerimata (van Noy et al., 2016).

Muutusi Eesti poliitikadokumentides on mõjutanud OECD ja Euroopa Liidu majandus- ja hariduspoliitiline ideoloogia, mis väljendub MFÕ diskursustes. Lisaks on MFÕ diskursuste kujunemisele avaldanud mõju MFÕ muutustele iseloomulikud suundumused: võimalused kõigile ja kõikjal, juurdepääs ja jätkuvus, paindlikkus ja võimaluste mitmekesisus, mis ei esine veel „Eesti elukestva õppe strateegias 2020“. Diskursuse muutuste taustal ilmneb mitteformaalõppega seotud mõistestiku mitmetähenduslikkus ja variatiivsus. Sarnaste tulemusteni on jõutud ka varasemates uurimustes (Livingstone, 2001; Naumanen \& Rinne, 2008; van Noy et al., 2016). Analüüsi põhjal võib eristada viit MFÕ põhidiskursust: keskkonna-, eristumis-, kaasamis-, süsteemi- ja tunnustamisdiskursust. Poliitikadokumentides kajastunud MFÕ eesmärkide, sihtrühmade, viiside ja võimaldajate mitmekesisuses ilmnesid spetsiifilised aladiskursused: võimalused ja kaasamine, tegevused ja keskkond, erinevused ja sarnasused, süsteem ja osa, formaalne ja sisuline tunnustamine. Seejuures on aladiskursused ambivalentsed, olles konstrueeritud näiliselt vastandlike tähen- 
duste kaudu: MFÕ on kõigile - MFÕ kaasab eksplitsiitselt eri sihtrühmi; MFÕ toimub mitteformaalses keskkonnas - MFÕ tegevused loovad MFÕ keskkonna; MFÕ on sarnane teiste óppimisviisidega - MFÕ eristub teistest óppimisviisidest; MFÕ on süsteem - MFÕ on süsteemi osa.

Selline näiline vastandlikkus võib osutuda vastuoluliseks. Aladiskursus MFÕ on kõigile võib muuta MFÕ tajutavalt elitaristlikuks, eeldades vaikimisi, et kõigile ongi tagatud juurdepääs ja võimalused õppimiseks ning kedagi ei ole tarvis toetada. Nii tekib vastuolu „Eesti elukestva õppe strateegia 2020“ põhimõtetega. Aladiskursus MFÕ kaasab eksplitsiitselt eri sihtrühmi võib teisalt MFÕ sihtrühmi sotsiaalselt tõrjuda, kõrvale heita, olgugi et kontseptuaalselt on mitteformaalne haridus demokraatlik ja mõeldud kõigile, kes soovivad õppida (vt Field, 2006). Seega on vaja mõlema diskursusega samal ajal suhestuda.

Kriitilise diskursuse ja poliitikaradade analüüsi meetodite kombineerimine on uudne lähenemisviis, mis võimaldab analüüsida tunnuspõhise otsinguga leitud poliitikadokumente ja MFÕ tähendusi. See, et sellist kombinatsiooni haridusvaldkonna rahvusvahelistes uuringutes ei ole kasutatud, seab meie uuringule aga piirangud, kuna puudub võrdlus varasemate uuringutega. Praeguse uuringu fookus oli MFÕ diskursustel ning vähem diskursuste sotsiaalsel mõjul. Edasistes uuringutes keskendume sidusrühmade arusaamadele, kaasates valimisse haridusvaldkonnaga seotud strateegiate koostajaid, töörühmade liikmeid, mitteformaal- ja täiskasvanuõppe ning noorsootöö praktikuid, täiskasvanute koolitajaid ja noorsootöötajaid, mitteformaalses õppes osalejaid. Lisaks võtame fookusesse MFÕ rakendamise praktikad, sh keskkonnad, meetodid ja tunnustamise.

\section{Kasutatud kirjandus}

Aava, K. (2010). Eesti haridusdiskursuse analüüs. Tallinna Ülikooli sotsiaalteaduste dissertatsioonid, 44. Tallinna Ülikool: Tallinna Ülikooli Kirjastus.

Autio, T., Kuurme, T., \& Mikser, R. (2013). Haridus. R. Mikser (toim), Haridusleksikon (lk 69-77). Tallinn: Eesti Keele Sihtasutus.

Åkerlind, G. S. (2005). Variation and commonality in phenomenographic research methods. Higher Education Research \& Development, 24(4), 321-334.

https://doi.org/10.1080/07294360500284672

Berger, P. L., \& Luckmann, T. (2018). Tegelikkuse sotsiaalne ülesehitus. Tartu: Ilmamaa.

Bock, J. C., \& Bock, C. M. (1989). Nonformal education policy: Developing countries. In C. J. Titmus (Ed.), Lifelong education for adults: An international handbook (pp. 64-69). Oxford: Pergamon Press. https://doi.org/10.1016/B978-0-08-030851-7.50023-0

Brennan, B. (1997). Reconceptualizing non-formal education. International Journal of Lifelong Education, 16(3), 185-200. https://doi.org/10.1080/0260137970160303 
Brookfield, S. (1986). Understanding and facilitating adult learning: A comprehensive analysis of principles and effective practices. San Francisco: Jossey-Bass.

Cohen, L., Manion, L., \& Morrison, K. (2000). Research methods in education (5th ed.), London: Routledge Falmer.

Colley, H., Hodkinson, P., \& Malcolm, J. (2003). Informality and formality in learning: A report for the Learning and Skills Research Centre. London: Learning and Skills Research Centre.

Coombs, P. H., \& Ahmed, M. (1974). Attacking rural poverty: How nonformal education can help. Baltimore: John Hopkins University Press.

Coombs, P. H., Prosser, R. C., \& Ahmed, M. (1973). New paths to learning for rural children and youth. New York: UNICEF International Council for Educational Development.

Cort, P. (2014). Trailing the unpredictable pathways of European Union Lifelong Learning Policy. In M. Marcella \& J. Holford (Eds.), Adult education policy and the European Union theoretical and methodological perspectives (pp. 127-140). Rotterdam: Sense Publishers.

Delors, J. (1999). Õppimine - varjatud varandus. 21. sajandi hariduse rahvusvahelise komisjoni aruanne UNESCOle. Tartu: Greif.

Duke, C. (2001). Lifelong learning and tertiary education: The learning university revisited. In D. N. Aspin, J. D. Chapman, M. Hatton, \& Y. Sawano (Eds.), International handbook of lifelong learning (pp. 501-527). London: Kluver.

Eensaar, T. (2003). Elukestva õppe põhiterminoloogia inglise-eesti seletav sõnastik Euroopa Komisjoni dokumentide põhjal (magistritöö). Tartu: Tartu Ülikool.

EEÕS 2014 = Eesti elukestva óppe strateegia 2020 (2014). Tallinn: Haridus- ja Teadusministeerium. Külastatud aadressil https://www.hm.ee/sites/default/files/strateegia2020.pdf.

Ertl, H. (2006). European Union policies in education and training: The Lisbon agenda as a turning point? Comparative Education, 42(1), 5-27. https://doi.org/10.1080/03050060500515652

EÕS 2005-2008 = Elukestva óppe strateegia 2005 (2005). Haridus- ja Teadusministeerium. Külastatud aadressil https://www.digar.ee/arhiiv/et/perioodika/12756.

Fairclough, N. (2001). Language and power. London: Longman.

Fairclough, N. (2010). Critical discourse analysis: The critical study of language (2nd ed.). Harlow: Longman.

Field, J. (2006). Lifelong learning and the new educational order (2nd ed.). Stoke-onTrent: Trentham Books.

Fordham, P. (1993). Informal, non-formal and formal education. INCED, DCE paper 4. Coventry: University of Warwick.

Foucault, M. (2005). Teadmiste arheoloogia. Tartu: Tartu Ülikooli Kirjastus.

Gergen, K. J. (2009). An invitation to social construction. London: Sage.

Gustavsson, B. (2000). Haridus kaasajal. Hariduse võimalustest ja tingimustest kaasaegses ühiskonnas. Tallinn: Eesti Vabaharidusliidu Kirjastus.

Haaristo, H-S. (2016). Eesti elukestva õppe strateegia 2020 tulemusraamistiku analüüs. Tallinn: Poliitikauuringute Keskus PRAXIS.

Hacking, I. (1999). The social construction of what? London: Harvard University Press. 
Halliday, M. A. K. (2005). On matter and meaning: The two realms of human experience. Linguistics and the Human Sciences, 1(1), 59-82.

https://doi.org/10.1558/lhs.2005.1.1.59

HKS 2014 = Maanso, V., Erelt, T., Kadakas, M., Kala-Arvisto, U., Kraav, I., Puksand, H., Tamm, E., \& Unt, I. (toim) (2014). Hariduse ja kasvatuse sõnaraamat. Tallinn: Eesti Keele Sihtasutus.

Holford, J., \& McKenzie, L. (2013). Conceptual model and questionnaire. Unpublished working paper: LLLight'in'Europe Project Deliverable 5.1. Nottingham: University of Nottingham.

Hoppers, W. (2006). Non-formal education and basic education reform: A conceptual review. Hamburg: UNESCO, International Institute for Educational Planning. Retrieved from https://unesdoc.unesco.org/ark:/48223/pf0000144423.

Jarvis, P. (1987). Adult learning in a social context. London: Croom Helm.

Jarvis, P. (1998). Täiskasvanuharidus ja pidevõpe. Teooria ja praktika. Tallinn: SE\&JS.

Jarvis, P. (1990). An international dictionary of adult and continuing education. London: Routledge.

Jarvis, P. (Ed.) (2002). The theory and practice of teaching. London: Kogan Page.

Jarvis, P. (2011). Learning: The experience of a lifetime! L. Jõgi \& K. Krabi (toim), Raamat óppimisest. Õppides täiskasvanuks - óppimine erinevates perspektiivides (lk 28-47). Tallinn: Tallinna Ülikool.

Jõgi, L., Jääger, T., Leppänen, R., \& Rinne, R. (toim) (2008). Eesti ja Soome haridus ning muutused EL-i hariduspoliitikas 1990-2000. Tallinn: Tallinna Ülikooli Kirjastus.

Kiilakoski, T., \& Kivijärvi, A. (2015). Youth clubs as spaces of non-formal learning: professional idealism meets the spatiality experienced by young people in Finland. Studies in Continuing Education, 37(1), 47-61. https://doi.org/10.1080/0158037X.2014.967345

Kleis, R. J., Lang, C. I., Mietus, J. R., \& Tiapula, F. (1973). Non-formal education: The definitional problem. Program of studies in non-formal education. Discussion Papers, 2. Michigan State University.

Knowles, M., S. (1970). The modern practice of adult education: Andragogy versus pedagogy. New York: New York Association Press.

Lengrand, P. (1975). An introduction to lifelong education. London: Croom Helm.

Livingstone, D. W. (2001). Adults' informal learning: Definitions, findings, gaps and future research. NALL Working Paper, 21, Centre for the Study of Education and Work, OISE/TU.

Lockhart, A. S. (2016). Non-formal and informal programs and activities that promote the acquisition of knowledge and skills in areas of Global Citizenship Education (GCED) and Education for Sustainable Development (ESD). Global Education Monitoring Report: UNESCO.

Milana, M., \& Holford, J. (Eds.) (2014). Adult education policy and the European Union: Theoretical and methodological perspectives. Rotterdam, Boston, Taipei: Sense Publishers.

Märja, T., Jõgi, L., \& Lõhmus, M. (2003). Andragoogika. Raamat õppimisest ja õpetamisest. Tallinn: Kirjastus ILO. 
Naumanen, P., Leppänen, R., \& Rinne, R. (2008). Euroopa Liidu muutuv hariduspoliitika. L. Jõgi, T. Jääger, R. Leppänen, \& R. Rinne (toim), Eesti ja Soome haridus ning muutused EL-i hariduspoliitikas 1990-2000 (lk 193-273). Tallinn: Tallinna Ülikooli Kirjastus.

Naumanen, R., \& Rinne, R. (2008). Euroopa Liidu hariduspoliitika ja Soome hariduspoliitilised suundumused. L., Jõgi, T. Jääger, R. Leppänen, \& R. Rinne (toim), Eesti ja Soome haridus ning muutused EL-i hariduspoliitikas 1990-2000 (lk 274-294). Tallinn: Tallinna Ülikooli Kirjastus.

Norqvist, L., \& Leffler, E. (2017). Learning in non-formal education: Is it 'youthful' for youth in action? International Review of Education, 63(2), 235-356. doi: $10.1007 / \mathrm{s} 1115$

Raud, R. (2013). Mis on kultuur? Sissejuhatus kultuuriteooriatesse. Tallinn: Tallinna Ülikooli Kirjastus.

Rinne, R., Kallo, J., \& Hokka, S. (2004). Liian innokas mukautumaan?: OECD:n koulutuspolitiikka ja Suomen vastauksia. Kasvatus, 35(1), 34-35.

Rogers, A. (2003). What is the difference? A new critique of adult learning and teaching. Leicester: NIACE.

Romi, S., \& Schmida, M. (2009). Non-formal education: A major educational force in the postmodern era. Cambridge Journal of Education, 39(2), 257-273. https://doi.org/10.1080/03057640902904472

Sang, J. (1983). Eitus eesti keeles. Tallinn: Valgus.

Shukla, P. (1983). Administration of education in India. New Delhi: Vicas.

Taru, M., Pilve, E., \& Kaasik, P. (2015). Noorsootöö Eestis 19. sajandi keskpaigast kuni 21. sajandi esimese kümnendi lõpuni. Tallinn: Eesti Noorsootöö Keskus.

Tought, A. M. (1971). The adult's learning projects: A fresh approach to theory and practice in adult learning. Toronto: Ontario Institute for Studies in Education.

Van Noy, M., James, H., \& Bedley, C. (2016). Reconceptualizing learning: A review of the literature on informal learning. Rutgers: Education and Employment Research Center. 
Lisa. Analüüsitud poliitikadokumendid radade kaupa

\begin{tabular}{ll}
\hline \multicolumn{1}{c}{ Nimetus } & \multicolumn{1}{c}{ Tekstisisene viide $^{12}$} \\
\hline Elukestva õppe poliitikarada & \\
Täiskasvanute koolituse seadus, 1993 & E_Õ_1993 \\
Täiskasvanute koolituse seadus, 2015 & E_Õ_2015 \\
Elukestva õppe strateegia 2005-2008 & E_S_2005 \\
Haridus ja koolitus 2020 & E_EL_2009 \\
Eesti elukestva õppe strateegia 2020 & E_S_2014 \\
Täiskasvanuhariduse programm 2018-2021 & E_P_2016 \\
Kutseharidusstandard & E_Õ_2013/2018 \\
Kõrgharidusstandard & E_O_2008/2018 \\
Noortepoliitika rada &
\end{tabular}

Uus hoog Euroopa noortele. Euroopa Komisjoni valge raamat N_EL_2001

Noorsootöö strateegia 2006-2013

N_S_2006

Noortevaldkonna arengukava 2014-2020

N_A_2013

\section{Heaolupoliitika rada}

Säästev Eesti 2021

H_S_2005

Laste ja perede arengukava 2012-2020

H_A_2011

Kodanikuühiskonna arengukava 2015-2020

H_A_2015

Heaolu arengukava

H_A_2016

\section{Kultuuripoliitika rada}

Eesti keele arengukava 2011-2017

Ku_A_2010

Keeleseadus

$\mathrm{Ku}$ _O__2011

Lõimumisvaldkonna arengukava „Lõimuv Eesti“

Ku_A_2012

Kultuuripoliitika põhialused aastani 2020

Ku_S_2013

\section{Majanduspoliitika rada}

Eesti infoühiskonna arengukava 2020

M_A_2013

Eesti regionaalarengu strateegia 2014-2020

M_S_2014

Konkurentsivõime kava „Eesti 2020“

M_A_2017

\section{Kliimapoliitika rada}

Kliimamuutustega kohanemise arengukava aastani 2030

K_A_2016

Kliimapoliitika põhialused aastani 2050

K_S_2017

12 Tekstisisene viide moodustus valdkonna (E - elukestva õppe poliitika, $\mathrm{N}$ - noortepoliitika, $\mathrm{H}$ - heaolupoliitika, Ku - kultuuripoliitika, M - majanduspoliitika, K - kliimapoliitika) ja dokumendiliigi (EL - ELi raamdokument, Õ - õigusakt, S - strateegiadokument, A arengukava, $\mathrm{P}$ - programm) tähistusest ning dokumendi kehtestamise aastaarvust. 


\title{
Construction of meaning of 'non-formal learning' in policy documents
}

\author{
Katrin Karu ${ }^{\text {a1 }}$, Larissa Jõgi ${ }^{a}$, Ilona-Evelyn Rannala ${ }^{a}$, \\ Triin Roosalu ${ }^{\mathrm{b}}$, Lianne Teder ${ }^{\mathrm{a}}$, Halliki Põlda ${ }^{\mathrm{a}}$ \\ ${ }^{a}$ School of Educational Sciences, Tallinn University \\ ${ }^{b}$ School of Governance, Law and Society, Tallinn University
}

\section{Summary}

The purpose of this paper is to explore how the discourse of 'non-formal learning' is constructed in policy documents and to discuss its meanings.

Non-formal education and/or non-formal learning is a highly complex phenomena and can be approached from different analytical and theoretical perspectives. As concepts, non-formal education and non-formal learning have intrigued many authors who admit that confusion with terms and meanings is obvious (Colley et al., 2003; Duke, 2001; Rogers, 2003). Non-formal education and non-formal learning thematically stand close as terms and have various meanings and contexts. 'Non-formal' in education and learning contexts does not have one clear content and focus - for example, this makes scholars, policymakers, professionals, adult educators and youth workers struggle to understand, explain and develop their practice.

Although there have been philosophical discussions about non-formal education and long humanistic traditions in adult education in Europe (Gustavsson, 2000; Jarvis, 1998; Rogers, 2003), the concept of education and learning has been challenged. Since 1973 when Coombs, Prosser, and Ahmed (1973) submitted their report to the World Bank, education has often been defined according to its functions and formality level as formal, non-formal and informal. The main discourse of non-formal education in the 1970's was 'education for everyone' with separation between formal and non-formal education on the way: non-formal education was seen as learning happening outside of formal education institutions. Later in the 1980's non-formal education was seen as complementing formal education or adding value to it (Norqvist \& Leffler, 2017; Romi \& Schmida, 2009). Since the 1990's the discourse of nonformal education and learning became more oriented on capabilities. Since 2000 and beyond we see under 'capabilities' discourse more clearly also 'lifelong learning' framework being constructed and 'non-formal learning' used in this

School of Educational Sciences, Tallinn University, Narva Road 25, 10120 Tallinn, Estonia; katrin.karu@tlu.ee 
context. The scene where educational policy (together with goals, terms and concepts) was formed and changed cannot be forgotten - before the Maastricht Agreement the European Union was somewhat cautious in influencing the educational policies of member states, but, after the Agreement was ratified in 1992 they 'pushed' strongly for more cooperation, and clearly stated in the Lisbon Strategy that economic growth together with a well functioning employment market are strategic EU goals to be fulfilled through education (Ertl, 2006; Naumanen et al., 2008).

Therefore we argue, based on the main principles of social constructionism (Gergen, 2009), that the way non-formal education and/or non-formal learning is constructed is influenced by the interaction between different stakeholders involved, ideology, by different agreements made in certain contexts, and by the language used. We focused our research on understanding how the meanings of non-formal learning are constructed in Estonian policy documents. There is no systematic research or reliable data about non-formal learning and education in Estonia, and no analysis of how the concept has evolved, or terminology that has been used in texts and practice. The conceptual and terminological complexity on one side and its rich variety on the other side posed a research problem: what are the sub-discourses and social meanings of non-formal learning discourses and how is non-formal learning and non-formal education described and presented in Estonian strategic policy documents. The research focuses on the post-Lisbon Strategy period up to now (2000-2018) and looks at the changes taking place in the discourse of non-formal learning.

The sources for the data analysis were Estonian strategic policy texts and documents. Empirical data which are presented in this paper, were gathered from 23 Estonian policy documents which were selected from 78 documents that were on the Estonian Government websites and the Estonian legislation official websites Riigi Teataja using the word 'non-formal'. Further selection was made by the word search (here for clarity in Estonian) 'mitteformaalne õpe,' 'mitteformaalne õppimine', 'mitteformaalne haridus' 'mitteformaalharidus' (non-formal learning and non-formal education in shorter and longer versions) and 'vabaõpe', 'vabaharidus' (translates as liberal learning and liberal education).

Critical discourse analysis (Fairclough, 2001) and the policy trail method (Cort, 2014) were combined. The policy trail method was adapted to describe the policy documents by fields over time, focusing on how these presented the dominant function, the main target groups, and spaces and methods of nonformal learning/education. The critical discourse analysis was then applied to explore the meanings of non-formal learning concepts as used in the policy documents. 
Five main non-formal learning discourses were determined, each consisting of two sub-discourses. The discourse of non-formal settings was made up of two different approaches to non-formal education: either it was seen as learning and education taking place in non-formal settings only, or, as a radical alternative, non-formal learning and teaching activities were seen as shaping the non-formal learning experience, even if within formal education settings. The discourse of difference suggested that non-formal education and learning is either similar to the other kinds of learning or that it is different from other kinds of learning. The discourse of inclusion presents a variety of specific target groups explicitly or assumes that everyone has equal chances without checking if they really do. The fourth, system discourse sees the non-formal education and learning either as part of a larger more complex system, or as an entire complex system on its own. The fifth discoursive theme, that of recognition of non-formal education and learning, was, in fact, extending through the previous four. It opened up two sub-discourses, de facto recognition, and de jure recognition. These dimensions become important to defining what the concept of non-formal learning and education entails in Estonia.

Policy trail analysis showed that on the trail of lifelong learning and youth policy non-formal learning is seen as serving the needs of individuals (often in very specific knowledge and skills level), organisations and society in general. It can be argued that non-formal learning is attractive as a target or means of political goals and the non-formal learning concept is largely shaped by experts in that field. Self-affirmation as a citizen and a successful career were emphasised in policy documents.

Regarding the target groups of non-formal learning - it involves all people, but also certain age groups and different vulnerable groups - pointing to the two dimensions of the capabilities discourse as mentioned above. Environments of non-formal learning are not clearly visible through documents which can be explained with the definition of non-formal learning where differentiation between formal and non-formal is stressed and therefore it can be assumed that non-formal learning is always taking place outside of formal settings.

Keywords: non-formal learning, nonformal education, non-formal education, critical discourse analysis, policy trail method 